\title{
Death at Work: A Case Study on Constitutive Blanks in Nineteenth-Century Painting
}

IN PAINTING, THEN, the chief thing is the portrayal of a situation, the scene of an action. In this connection the first law is intelligibility." ${ }^{1}$ This requirement - and it may come as a surprise-is laid down in Hegel's Aesthetics. Even at the acme of the idealist philosophy of art, recognition was accorded to the necessity of offering a plausible, clearly understandable art to a greatly expanded public, one that was as imponderable as it was unknown. In their famous essay of 1798, "Über die Gegenstände der bildenden Kunst" (On the Objects of Plastic and Graphic Art), Goethe and Meyer stated with an unmistakable clarity:

We require of every work of art that it constitute a separate totality, and of every work of the plastic and graphic arts in particular that it express itself fully. It must be independent. The action presented, the object must be apprehended and understood for the most part without external assistance, without ancillary explanation that would have to be drawn from a poet or an historiographer. Just as we would find fault with a poem whose plot and motifs could be understood only from appended notes, so we have cause to be dissatisfied with paintings or statues whose meaning is not obvious to the eye, but must first be looked up in a book or recounted to us. ${ }^{2}$

However, the theory of art of this period did not construe the "law of intelligibility" in an abstract manner, nor did it require that this law be observed at any price. Submersion in an unproblematic reality, making the themes of art radically topical-what Hegel called "the subjective stress on the contemporary civilization" - was not what this theory had in mind. Intelligibility and action ("plot") are a closely linked pair of concepts in the idealist theory of art, as the quotation with which we began our discussion makes clear. By means of the condensation of the historical material - the manifest significance of the pictures as well as the depicted subject matter itself - the meaning of history, it was hoped, might be reached. In 1843 Ernst Förster wrote: "The historical conception in art is not concerned with the accidental happening, which is often understandable only for the participants, but instead with the content of an event, with that which remains intelligible for all and forever, with its meaning in history." 
Art's first answer to the demands of idealist theory, and even more to the demands of its environment, was Classicism-with its clear, easily grasped forms, its schematically arranged pictorial planes, its mechanistic ideal of composition, and its intense striving to render the "natural" language of bodies, gestures, and facial expressions. This art did not make things easy for itself. The previously mentioned demands from without, as well as an internal commitment to an exacting repertoire of subject matter and the ponderous genre of historical painting, resulted in a tremendous straining and broadening of the possibilities of the historical painting, indeed, as some believe, to the very limits of the medium. ${ }^{5}$ This ideal of an historical painting that "expresses itself" can be explained briefly, using as an example a well-known work that does not strive for extreme solutions to the tasks set for the historical painting but is simply executed with a high degree of consequence.

Pierre Paul Proudhon exhibited his imposing composition Justice and Vengeance Pursuing Crime in the Salon of 1808 (the work is now in the Louvre; fig. 1). ${ }^{6}$ The picture was intended for the great courtroom of the Palais du Justice. To the patron who commissioned the painting from him, the prefect of the Department of the Seine, Proudhon proposed first an allegorical composition: Nemesis, the winged goddess of vengeance, drags before the tribunal of justice a murderer, whose victims, a mother and her child, lie stretched out on the ground in front of the throne. Justitia is flanked by the allegorical figures of strength, wisdom, and moderation (fig. 2). ${ }^{7}$ About this preliminary sketch Proudhon wrote:

Filled by this idea [of finding a suitable subject matter for the court], but little taken with all the materials that history places at our disposal for this purpose, and that are either too obscure or too worn out, I took recourse to the nature of the matter itself, which then put in my hands everything that was suitable and provided the subject matter for an especially impressive picture: it is appropriate for every age and belongs to every people, announces and explains itself, and at the same time shows the cause and its effect (il est de tout les temps, appartient à tous les peuples, s'anonce et s'explique de lui-même et présente en même temps la cause et son effet). ${ }^{8}$

This was the claim made by bourgeois art, and it has probably never been more precisely and clearly formulated. But did the execution of the picture accord with this claim? How did five allegorical figures spring from the "nature of the matter itself"? Through which indices did melancholy Justitia, sitting motionlessly on her throne, show that she, as Proudhon says in the same article, "pronounces the crushing judgment that strikes all things fatally"? And how can the author of the quoted lines maintain that his sketch shows both cause and effect, when nothing makes clear why the murderer has killed the woman and her child? Whether owing to his own recognition of the problem, or because of criticism from his patron, Proudhon subsequently revised the composition in such a way that it corresponded to his programmatic statements. A description 


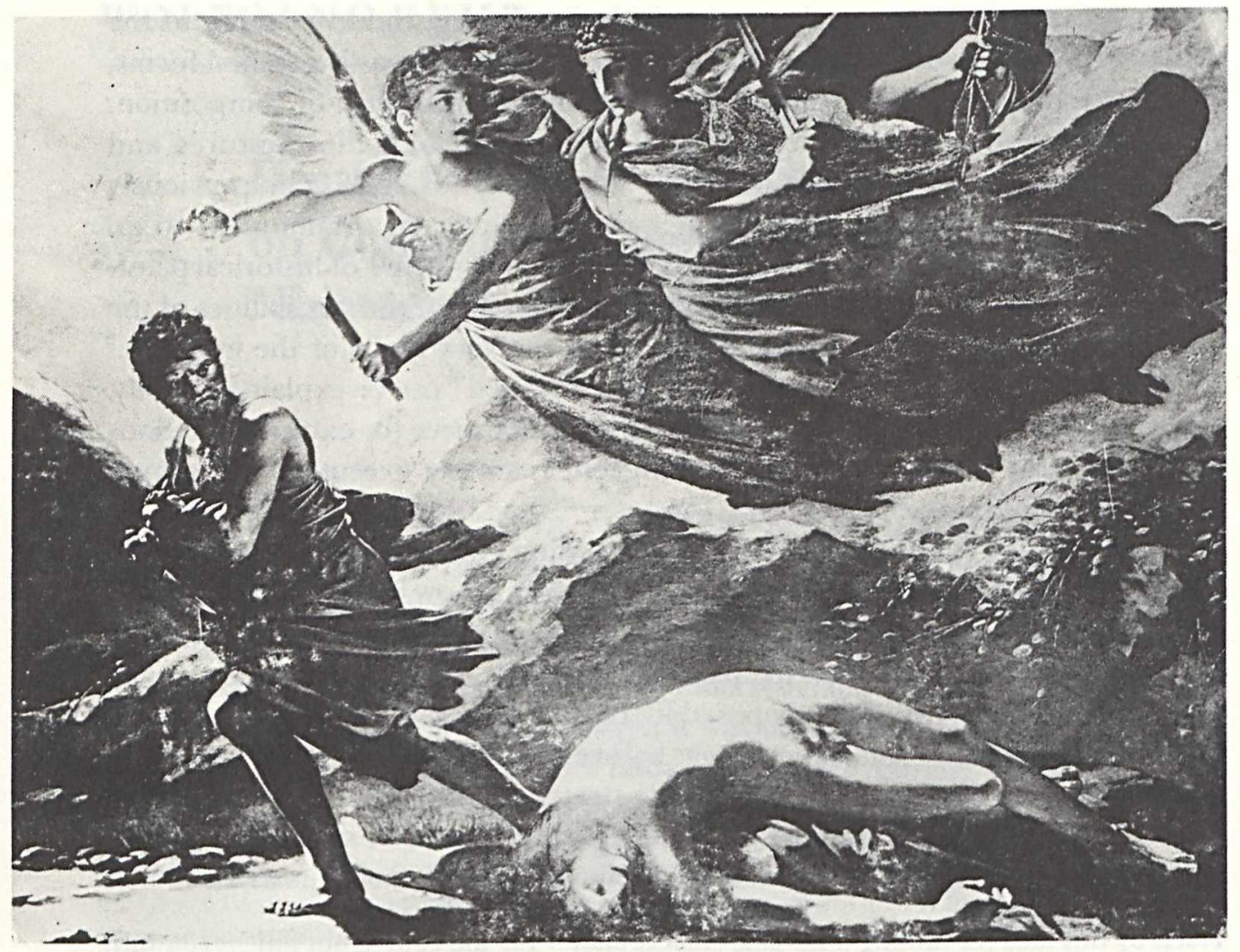

FIgure 1. Pierre Paul Proudhon, Justice and Vengeance Pursuing Crime, 1808. Oil on canvas. The Louvre, Paris. Photo: University of Marburg.

of the final version indicates how Proudhon's conception of the picture developed, namely into a "situation," a "scene of an action": "In a wild and distant spot, covered by the veil of night, the greedy criminal strangles his victim, takes the gold, and looks once more to see if there remains any spark of life which might uncover his crime. The thoughtless one! He did [sic] not see that Nemesis, that terrible handmaiden of Justice, follows, and, like a vulture dropping on its prey, soon will catch him and hand him over to her unyielding companion." ${ }^{9}$

In every respect there has been an increase in the motivation shown in the picture: to be sure, the deed has already been done, but it is obvious how it has come about. There is the weapon, and there are the wounds; there is the booty, and there is the one who has been despoiled, stripped bare; there is the criminal, dark, given over entirely to gathering himself together, active, fleeing, quitting the picture, and there is the light-colored and naked (innocent) victim, stretching 


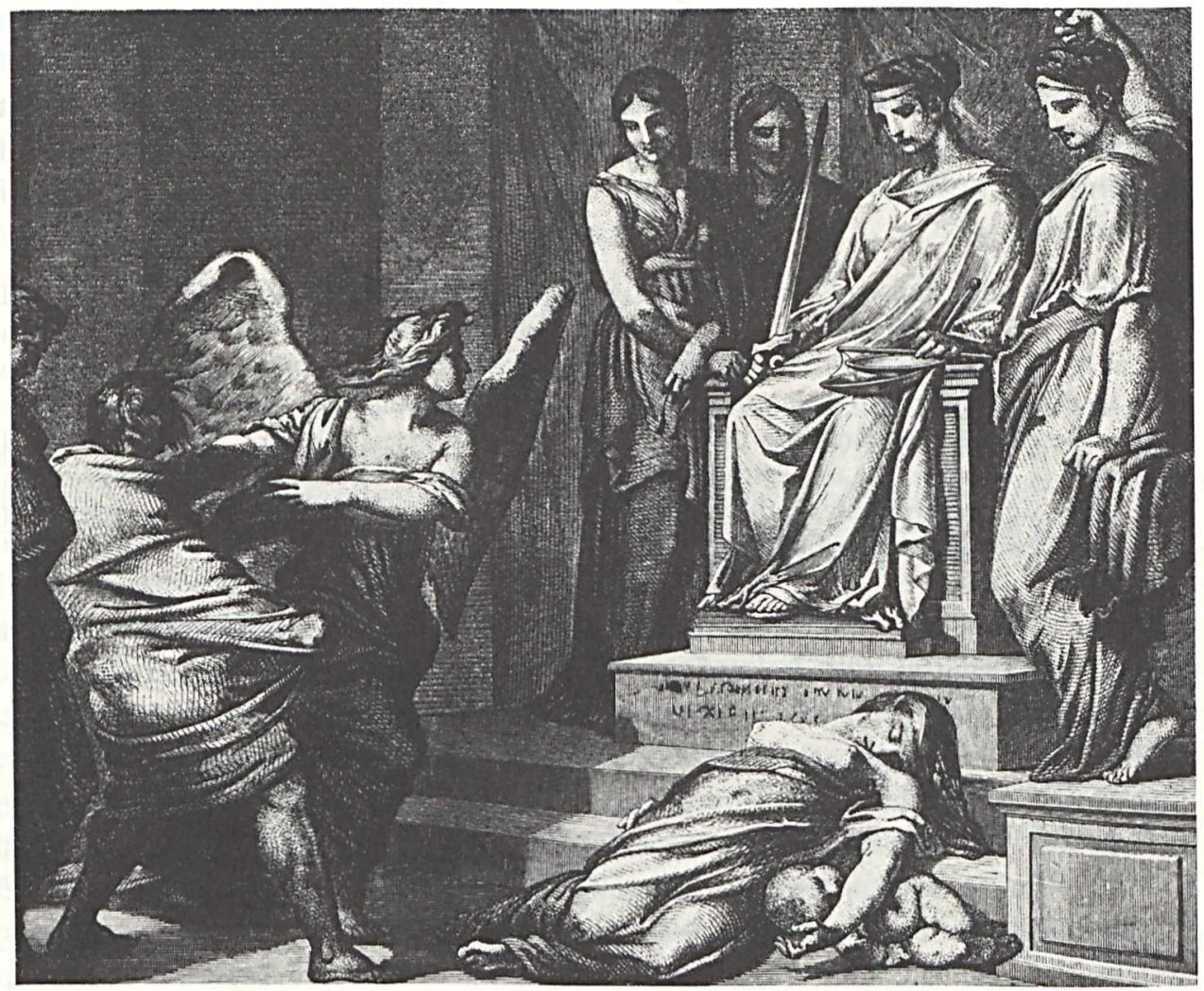

Figure 2. Pierre Paul Proudhon, earlier version of Justice and Vengeance Pursuing Crime. Reproduced after Gazette des beaux-arts 6 (1860).

forth all his limbs, passive now for all eternity, remaining in the picture and confirming it. A clearly perceptible network of oppositional relations binds the two earthly protagonists together; cause and effect show and "explain themselves." The site of the action also plays its part: night and a desolate place provide the "classical" setting for the crime; the bush and the rock in the background form shapes parallel to the victim who has been laid low, while the active diagonal of the fleeing criminal is reinforced by the dark formation of rock behind him. The allegorical figures, too, now impress the beholder as being more motivated: as embodiments of supernatural powers, the upper region, the top half of the picture, belongs to them. Even the beholder who is not able to grasp the meaning of torch, sword, and scales would understand the "natural form" of the figurative, allegorical beings. Their heavy and yet energetic mass corresponds to the elements that are arranged in a semicircle beneath them; it corresponds to the zone 
of the victim. Where the curves diverge from each other, on the left, they leave the perpetrator free-only temporarily, though, as Nemesis' clutching gesture and the resolute movement of Justitia make clear. The allegories, too, are part of the cause-effect relation here; they are acting figures. "At the heart of such reasoning," explains Rosalind Krauss, writing about the classicist manner of composition,

is the notion of causality, of the connection between effects and their causes which depend for their very relatedness upon the passage of time. In the eighteenth and nineteenth centuries ambitious painters and sculptors accepted without dispute the notion that time was the medium through which the logic of social and moral institutions revealed itselfhence the exalted position they gave to history painting as a genre and to historical monuments. History was understood to be a kind of narrative, involving the progression of a set of significances that mutually reinforce and explicate each other, and that seem driven as if by a divine mechanism toward a conclusion, toward the meaning of an event. ${ }^{10}$

The depiction of subject matter of universally valid significance in an understandable way without the help of prior literary treatment of the subject matterthere can be no doubt that the entire nineteenth century profited from what painting accomplished around 1800. When motivational art, for which Proudhon's great composition shall here serve as a representative, has developed the feeling for the dramatic or even merely scenic connection of a picture's elements with each other to this degree, then only a new ordering of those elements, of almost negligible extent, is required in order to replace the last remaining "conventional signs," the allegorical figures. Once that has been achieved, would the immanent goal of bourgeois art then have been definitively attained-the "picture that explains itself," the visual language that "belongs to all ages and to all nations," consisting of "words" made of what is manifestly intelligible in everyday life?

If one considers the quantitative shifts in the production of paintings during the nineteenth century, this question must be answered in the affirmative. The kinds of paintings most in demand - portraits, landscapes, and genre picturesdoubtless strengthened the artists' claim that they were making comprehensible pictures; they stabilized aesthetic communication by acknowledging the "dictates of reality." The same question, however, would have to be answered with a "no" if one were to give thought to the great difficulties that realist artists had with their public. ${ }^{11}$ Reality - as has been said often enough-exists only as a concept defined by common agreement, and realism is not, as has been asserted, the attempt "to safeguard consciousness from doubt." But it would be a mistake to distinguish overhastily here between an affirmative and a critical realism, between run-of-the-mill mass production and complex creations. That the relations between all levels of language are very intimate and productive may today be considered just as much an established fact as that nineteenth-century painting often pre- 
serves critical capacities and brings them into play where one least expects to find them. Even, and especially, a realism that was well received by the public did not only supply complete pictures that were clearly and immediately understandable, did not only rest on the prior achievements of classicist painting, but, in addition, broadened and strained the possibilities of its medium and the abilities of its recipients. ${ }^{12}$

\section{II}

In the following discussion use will be made of a concept that is introduced, with some hesitancy, into the terminology of art history from that of literary criticism. In the works of Roman Ingarden and Wolfgang Iser, respectively, this concept is referred to as "place of indeterminacy" and "blank" or "gap." In film aesthetics a related notion has had currency for some years; it is called, in both French and English, "suture," meaning "seam," the line of junction between the viewer and the work; ${ }^{13}$ here one could perhaps also speak of a tying of the viewer into the work. These two concepts are not coextensive in their meanings; rather, they complement one another. They do, however, share the fundamental premise that every work of art is left incomplete, in a precisely focused manner by its maker, in order that it might be brought to completion in and through the beholder. In the formulation of this premise, the emphasis is placed on the precisely focused, programmatic, or constructive character of the art work's incompleteness.

In view of the many concrete and materially effective aids to understanding that the plastic and graphic arts offer the beholder, the question of what could justify the adoption of such a theoretical concept by the disciplines concerned with those arts automatically arises. In a certain respect, Lessing anticipated such a reservation in his Laocoön when he wrote: "Poetry shows us bodies only from one side, only in one attitude, only as regards a single property, and leaves everything else about these bodies indeterminate. Painting cannot do this. In it one part draws the other after itself; one quality entails the other. Painting must make everything definite." ${ }^{\prime 4}$ Are there then no places of indeterminacy in the plastic and graphic arts? What Lessing means in this short passage is clear: no one will require of a literary text that it reproduce its objects in the same detail as painting and sculpture. Does Virgil describe the coiffures of Laocoön and his sons? Does he consider it necessary to mention the nipples of their breasts and their navels? No-for the "natural signs" of art produce a more complete picture, showing more of the pertinent object, than does literature's "artificial" and selective capacity to present.

And yet the first sentence of the quotation from Lessing can also be applied to painting. One can, after all, say: "Painting shows us bodies only from one side, 
only in one attitude, only as regards a single property, and leaves everything else about these bodies indeterminate." One is then addressing the perspectival nature of painting, which Lessing, too, includes in his media-based aesthetics as an important category. In addition to other characteristics, the perspectival composition of painting also results in the withholding from the beholder of many aspects of the depicted scene-information about the objects shown, for example, but also moments of the scene's temporal dimension. For the system of linear perspective is a spacio-temporal one-this fact, too, Lessing established with clarity: in this convention of painting, the unity of space and the unity of time condition each other. As a result, "what precedes and what follows," and many aspects of the spatial continuum, remain indeterminate, potential blanks.

Lessing himself, in his famous definition of the "fruitful moment," put forward the demand that room must be left for the supplementing activity of the beholder: "Now that only is fruitful which allows free play to the imagination. The more we see the more we must be able to imagine; and the more we imagine, the more we must think we see." ${ }^{15}$ In Diderot, another theoretician of the picture's unity, of the picture as "machine," Lessing found support for his thesis: "When one paints, is it necessary to paint everything? For pity's sake, leave something to be supplied by my imagination."16 Thus even in the classicist theory of art, which calls for the complete picture that is intelligible in and of itself, we find insights into the relative indeterminacy even of graphic art. We also find a first suggestion that blanks are not necessarily the enemy of the picture that is "intelligible in and of itself" but instead are clearly among the things required for such a picture's actualization.

Now, it signifies little if a portrait withholds from us the rear view of a person, if a landscape withholds from us the back side of a house. Aesthetic perception does not differ from everyday perception in this regard. It is of no interest to us how the road in Proudhon's picture continues onward, or just where the light comes from, and the relief-like execution of the figures makes the beholder's supplying of their rear views completely superfluous. However, the fact that the culprit has eyes only for his victim, thinks only of his escape, and does not see what is brewing above him is a functional blank that the viewer must fill in. Only because he sees what the murderer does not see, and sees that the latter does not see it, does the picture's recipient understand "what happens next," as well as other things pertaining to the notions of justice, punishment, and violence besides. The work of art makes a claim to coherence and intentionality; at the same time it aims at achieving communication. The blanks contribute to effecting the cooperation of these determinations. Blanks create "essential conditions for communication," "for they set in motion the interaction that takes place between text and reader, and to a certain extent they also regulate it." As a means of structuring the process of reception they themselves cannot be "without structure," especially in view of the fact that their "function is performed by way of the formulated 
determinacies of the text" (or picture). ${ }^{17}$ Their principal function, like the aids to reception (i.e., what is determinate), is to link the communication between the picture and the beholder with the communication within the picture. Iser discusses this most important function of blanks in terms of a "potential connection." For texts, but easily also for pictures, blanks "are the unseen joints of the text, and as they mark off schemata and textual perspectives from one another, they simultaneously trigger acts of ideation on the reader's part. Consequently, when the schemata and perspectives have been linked together, the blanks 'disappear." 18 They can be considered an elementary matrix for the interaction of text and reader.

It might now seem as though blanks are the most important aids to the fulfillment of the "law of intelligibility," not obstacles, as was in fact to be expected. Still, communication is facilitated or impeded by fundamental relationships between determinate/indeterminate, closed/open, over-/underdetermined elements in the work. These relationships can be so constituted that blanks postpone or impede connection of a picture's constitutive elements, making perception of the picture difficult or disrupting it, even making the blanks themselves independent and displaying their willfulness at the expense of the ideal of problem-free communication. We would do well to examine these complex cases by means of an example.

\section{III}

The title of the work that I have chosen suffices to indicate its suitableness for our undertaking, for of itself the title causes the beholder difficulty. The Death of Marshal Ney by Léon Gérôme was exhibited originally, in the Salon of 1868, with the title December 7, 1815, 9 o'clock in the Morning (fig. 3). ${ }^{19}$ This appellation is at least as challenging as the picture itself. Little is expressed clearly; much is only intimated; most of what the picture is about has to be guessed or must already be known. The picture calls for an experienced and receptive viewer; the "law of intelligibility" seems not to hold any more for the picture's author, or at least not to have first priority for him. Contemporary criticism was not reticent about its doubts regarding such unconventional historical painting.

Just imagine that a century has passed, and that The Death of Marshal Ney is hanging in some European gallery. Then one will only be able to recognize, very generally, an act of violence that has been committed against a civilian, in a deserted spot, by a detachment of military which is now quitting the site of the happening and casting back furtive glances as though it felt itself caught. Just like those painters who cling only to the letters of the historical event, Monsieur Gérôme, too, runs the danger that in the future he will not be appreciated and understood. His undecided partisanship is alone enough to prevent the alert interest which awakens to life all important documents of history, from attaching itself to his pictures, which are undeniably executed with very great deliberation. Monsieur Vibert is, in comparison, much more understandable. ${ }^{20}$ 
That is what the otherwise open-minded Jules Grangedor wrote, a succinct but densely significant opinion to which we shall have to return in the course of the following discussion. The judgment of German art criticism was more global, but in its tendency it conformed to that of the French critics: "One cannot speak of dignity and self-respect in an art that presents such objects in such a manner. For a drunk lying in the gutter the humor would be lacking; for a Ney there would be lacking only-everything.... Who has the right to take as his subject human nature in its most shameful humiliation, in order to use it as an opportunity to show that he can admirably paint marks left by bullets in a plastered wall." ${ }^{21}$

The German critic is hitting home at a central feature of the painting. After the passage of more than a century, what we first take notice of in this picture hanging in a European gallery, the Graves Art Gallery in Sheffield, guided by its perspective and the lighting, and by the schooling we have received from modern painting, is the surface of a wall, a bare, besmeared stone wall covered with scratches, from which the plaster is flaking away, the street side of a long, low building that rapidly recedes and tapers perspectivally toward the left. This wall face can be considered a large fragment of pure painting, such as we find not seldom among the works of the most painstaking realists of the period after 1850. Yet we cannot dwell upon it for any length of time, for here we encounter a blank that functions as a "joint." Our regard slides from the wall into the picture's depth, or down to the prostrate dead man, and from him onward, following the line of the building and the tracks of wagon wheels in the road, into the perspectival depth of the composition, where a squad of uniformed soldiers is leaving the scene of the action and the picture.

Our regard is not, however, pulled on into the picture's depth and lost there. Instead, it is halted and redirected by the figure of the backward-looking man clothed in black, presumably the adjutant in command of the execution. His glance requires that it be interpreted generally as a "looking back"; it is not directed very precisely, and so returns us to the wall or to the dead man, regardless of whether we first followed the wall or whether we considered the dead man after looking at the wall and then went on into the depth of the composition.

Thus we find, after our first consideration of the painting, a compositional schema consisting of three elements presented as ideal types: a blank; a participant in the action, more accurately an object of the action; and an element helping to create the picture's perspective, more exactly a figure that helps to create the perspective and that is the representative of a group of participants in the action.

FIGURE 3 (opposite). Léon Gérôme, The Death of Marshal Ney, 1868. Oil on canvas. Graves Art Gallery, Sheffield, England. Photo: Museum. 
When we examine this last figure more closely, we ascertain that it is larger than the picture's perspectival construction, which can be verified with relative exactness, allows. Further, attention needs to be paid to the figure's direction of movement. In contrast to the soldiers, who are marching precisely parallel to the house wall and follow the stretch of road, the black-garbed man is executing a movement that will, upon its completion, bring him into the wake of the marching detachment; he is still coming from a direction in which the corpse also channels the viewer's attention. Just what the significance of this direction is can be surmised: the executed man stood in front of the light-colored section of the wall to the right; the firing squad stood facing him, outside of the picture. Following the execution, after the victim had fallen forward away from the wall, toward the squad of soldiers, the squad, in perfect order, had swung back onto the road. Thus the black-clothed man unites in himself a number of functions. He is a constituent of the perspective in an intradeictic sense; his look and the twist of his body stop the movement of our attention into the picture's depths and direct it back. He is a participant in the action; his role is not all that easy to establish, but the conclusion that he is concerned in a causal fashion with the result to be seen in the picture's foreground forces itself upon the viewer-the meaning that

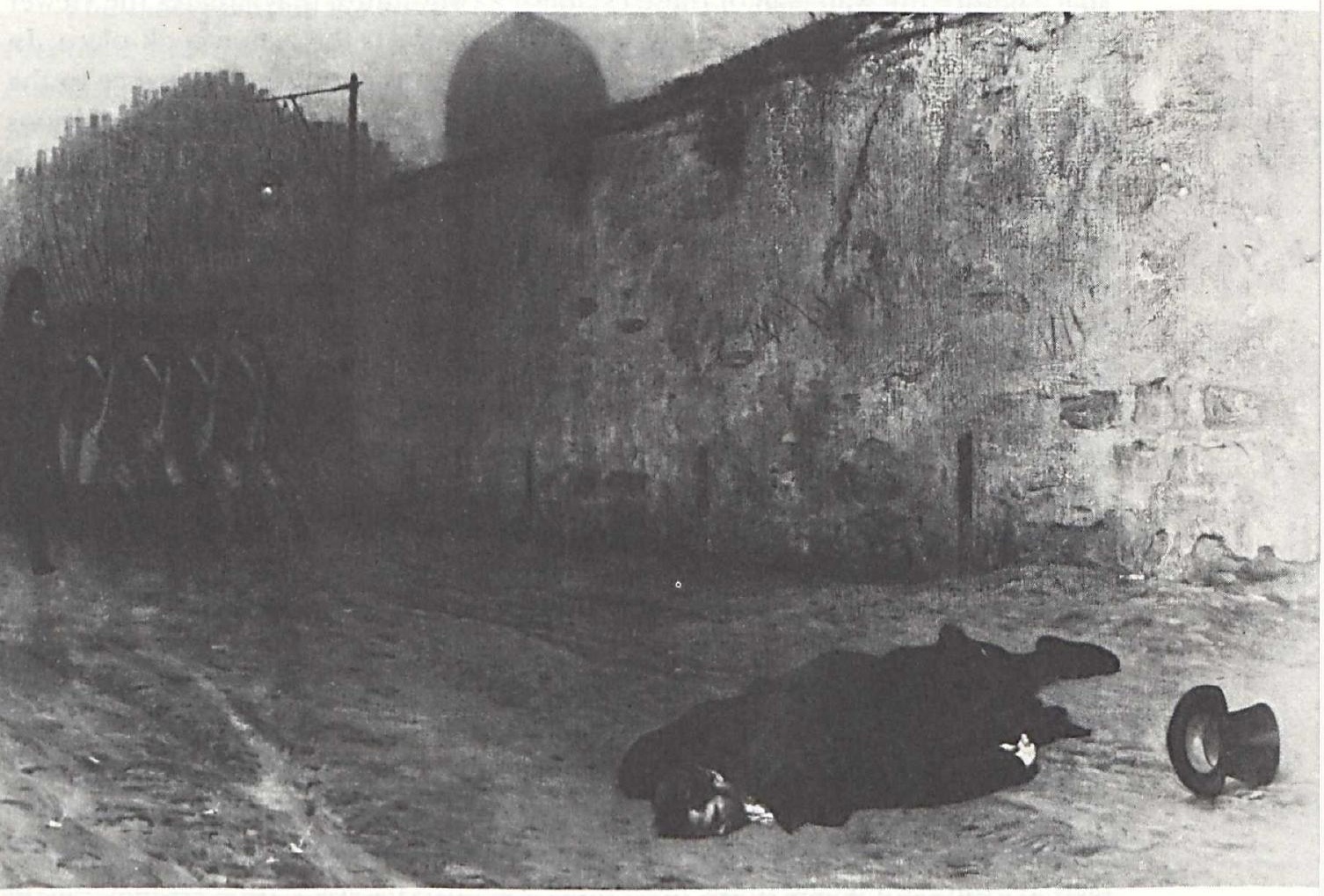

Death at Work: A Case Study 
has come to be attached to the motif would be sufficient to ensure that this happens. Recall Proudhon's painting: the culprit is looking back one more time on his victim, on the scene of the occurrence. In Gérôme's picture, the movement of the black-clothed man brings into the picture a part of the hors du champ, a part of the space in front of the picture. That this man, invested as he is with several functions, should become larger than his location within the picture's perspectival system permits seems only natural, and is, if one considers other works by Realists and Impressionists-it is nothing extraordinary for this period. Hence the rearward-looking man is a quite integral element of Gérôme's composition, an element that is motivated in several respects: he is an aid to the reception of the picture that has taken the form of a person; he confirms and helps us to grasp the significance of two large blanks - the wall and the space in front of the picture.

Let us now turn to the question-both of the space within the picture and of the space in front of the picture. A fundamental difference between Gérome's work and the classicist conception of Proudhon is the consequent and meaningful linking together of the two spaces in the former. The diagonal position of the scene, the extension of the wall beyond the picture's boundary on the right, the vectors that the backward-looking man and the dead man both direct into the space before the wall-all of these establish a continuum that situates the viewer and is also identified as a part of the space in which the action took place. In Proudhon's painting, the space in front of the painting has no relevance to the scene in the picture. From that space come no decisive or additional impulsions to the action. Indeed, as far as this frontward opening is concerned, Proudhon's painting reaffirms - in Michael Fried's words-the "highest fiction" of classicist painting, in which even the presence of the beholder at the depicted scene is out of the question. ${ }^{22}$ The isolated crime, and along with it the picture, loses its meaning if an observer is present as close at hand as the picture makes possible. So Proudhon integrates the function of the beholder, the all-seeing eye of Justice, into the picture, and personalizes it in the two allegorical figures. His picture pretends to be complete in itself.

Gérôme's picture is a different matter. In it the nonvisible area in front of the depicted scene has the task of supplying space for both the picture's action and its viewing. One can speak here of narrative space, also, and especially, with regard to the hors du champ. ${ }^{23}$ For what happened in the temporal phase preceding the depicted moment, what is no longer visible but is nonetheless of crucial importance for the action of the picture-namely, the firing squad, the shots, the execution of state power-all remains situated in the area before the picture, in the blank, invisible and yet present both in its traces in the picture described above and as picture. Space and time, the area before the picture and the area shown in the picture, the beholder and the depicted scene, blank and intelligible facts are interconnected in the most intimate way. The one element is incomplete 
without the other, and their relationship with one another is governed by the law of distance, which has very little to do with the "law of intelligibility" but a great deal to do with the law of tension.

This is made evident by the treatment of space within the picture. Proudhon's work is in accordance with Lessing's pronouncement that "the proper subject of painting" consists in the depiction of "things whose parts lie side by side" - surely this is the way that the "fitting relationship" between medium and subject matter that Lessing sought to determine for every art form is to be understood. ${ }^{24}$ The perpetrator of the crime still stands in immediate physical contact with his victim. The knife in his clenched fist is still pointed in the direction, indeed appears still to have the energy, of the fatal thrust-and above the scene already hover menacingly the goddesses of vengeance. The occurrence is so punctually condensed that one can hardly speak of a narrative space: a place is presented that in its symbolic expressivity gives support to the action but does not become the medium of narration. The distance of the elements participating in the action from each other, and of these from the beholder, remains always the same; perspectival depth, spatial distance as a means of recounting an action are unknown to Proudhon, while in Gérôme's painting we encounter them as essential devices of pictorial narration.

The movement of the squad of soldiers and the direction of its movement constitute the first, unproblematic narrative moment of Gérôme's picture. They establish a narrative direction: the group is quitting the site of the occurrence. More important and more critical is the distance between the soldiers and the dead civilian in the foreground, a distance that is expressed in the relative size of the figures and in the differential precision with which they are rendered, as well as in the empty stretch of road. A distance that has been traversed can be translated into time-no problem with that. Still there is the question: how much time and distance is admissible if one wants to maintain a causal relationship between two bodies that are drawing apart from each other? Gérôme is clearly working on this problem; however, he does not arrive at a "fitting relationship" among the elements of his composition. Rather, Gérôme puts such a heavy strain on the temporal and spatial extension of the participants in the depicted action that there can be no question either of "unity of the whole" or of the "concurrence of all parts for the attainment of a final purpose"-accepting Lessing's definition of "final purpose" as the clearly intelligible and consequent unfolding of an action. Once again a blank emerges, the third in this picture after the wall and the area in front of the picture. And once again what remains unoccupied has at least as much expressive power as the inanimate objects and human bodies.

When Gérôme extends this distance very far, then the strained, "unfitting" relationship, the tendential discontinuity, becomes an object of the beholder's attention, a bearer of the action shown in the picture and a means of expression. Space, the scene, appear as actors in the picture; this is the highest, most active 
form of narrative space (compare, purely quantitatively, how much of the painting's surface is given to the figures and how much to the setting in the works of Proudhon and Gérôme). Space, significant distance communicate something that the "machine" of the historical picture constructed with logical consistency clearly refuses to convey, and that is probably an experience specific to the era in question: the force of circumstances, of external fatality; the tendency to disjointedness, to lack of resolution, to profound fortuitousness. The emptiness surrounding the dead hero, the ostentatious desolation of this emptiness, also calls for a reading as an historical fact: according to the law regarding "normal" executions in effect at that time, the dead person had to remain lying for fifteen minutes at the site where the sentence had been carried out before he could be removed. The application of this law to a marshal and a peer of France had to be understood as a dishonor, as much so as the commonness of the place where the famous man was gotten rid of.

Realist painting was prepared to take the reality of these circumstances into account, even to let them exercise a guiding influence. It then could not prevent, and in all likelihood did not want to prevent, the object of historical painting from surreptitiously changing: in the place of history, happening; instead of manifest intelligibility, contingency; instead of sense, sensory data; instead of comprehension on the part of the beholder, suspense. Such were-expressed epigrammatically - the new options.

While Proudhon devotes half of his picture-using the criterion of mere quantity - to what preceded the depicted scene, the murder, and the other half to the future, the vengeance for the crime, the past's portion in Gérôme's picture goes counter to the whole; the painting of the "fruitful moment" gives way to a painting of the accomplished event. The conscious retreat from the idealist construction of history and of the picture does not just result in a changed attitude toward reality and to "School Mistress History" but also, of course, affects the artist's conception of his role, his responsibility to the public. A displacement of activities takes place-the artist is no longer the fabricator of solid data and relations; instead he arranges spaces and surfaces, which are open to the projective activity of the beholder. The old notion that art should "stimulate ideas in the beholder, but not demand them" proves brilliantly its applicability to the fragmented constructions of Realism. "It is the last, the making of demands on the beholder, that confronts us so maladroitly and clumsily in the more recent art, and must, by degrees, disgust us," complained a critic in 1844, looking back on the painting of the first half of the century. ${ }^{25}$ But the pictures that no longer make demands are nevertheless constructions like their predecessors. What has not changed is the fundamental condition of their existence: the fact that they must gain acceptance from a large, undefined public, in the salon, the art exhibition, and the marketplace. The forms of guidance of the reception of art, to 
put it elegantly, are effective in varying degrees, but they remain forms of guidance of the reception of art.

Blanks are structured, and they can function on several levels. ${ }^{26}$ The emptiness around the dead hero in combination with the departing soldiers expresses on the actional level a point of time in the sequence of events that can be determined with relative exactness. But this distance also needs to be understood symbolically - as the solitude of death, as dishonoring indifference. The capacity of the blank for investment with multiple meanings becomes most clear when we turn our attention back to the wall, which first attracted it. There, where apparently there is nothing, everything is in fact inscribed: history, history as painting, and the history of painting. Beginning from the empty wall we gained access to the picture, and we now return to it; the "joint" obviously has something to say. In the last moments of his life, Ney concealed the face of the wall. The blank of the wall is the blank left by Ney. The bullets that missed him scored the wall; the light lies on the scarred surface like the dead man's aura. This blank can be regarded as the intrapictorial counterpart of the area in front of the picture: the action that began there was left as a precipitate on the wall, as the marks of the bullets and as emptiness. Thus, Gérôme made perhaps the first, in any case the most remarkable, attempt to reduce in a picture history, or mere occurrence, which presents itself realiter in the four dimensions of space and time, radically to a surface. The fact that in his picture the surface in question is cropped on two sides in such a way that it loses its perspectival alignment and assumes a position that is parallel to the picture and tendentially without distance in the composition indicates a productive relation between the blank, which itself becomes a focus of the beholder's attention, and pure painting. When the level of the occurrence is peeled back, as is done here, then painting's field of action presents itself to view.

With this what was indeterminate should, strictly speaking, be sufficiently determined. But Gérôme goes even further. He adds to the wall's already large repertoire of signs the highly determined code of written language. Halfway up the wall, vertically over the corpse, are written the blurred words "VIVE LEMPEREUR," which someone has crossed out with diagonal strokes. To the right of this inscription the same text begins again. But only the word "VIVE" has been completed, and its last letters are indistinct. The rest is missing entirely, this time-one might believe-dissolved in the auratic light, erased by the hail of bullets. That is an artifice of the painter, which acknowledges the fact that this wall of the Avenue de l'Observatoire with its six pockmarks from the firing squad's bullets was soon piously "read" by many and inscribed further, with anti-Bourbon slogans that made it necessary to plaster over the face of the wall and to paint it repeatedly_- "but the faithful did not let themselves be discouraged."27 This "surface" version of historiography might have served as a model for Gérôme, indeed 
might have exercised a compelling influence on him. Nonetheless, with this overcoding in his picture Gérôme has, in our opinion, given his audience too much of a good thing. Manet, who was occupied, as is well known, with topics similar to those of Gérôme, would never have included in the picture such auxiliary information. Gérôme is an artist who takes into consideration his audience's reactions, and who counters habitual expectations on the part of the beholder with well-aimed shocks and carefully calculated discontinuities. He puts a great strain on both the means he employs and his public, but not beyond the limits of what they can bear. ${ }^{28}$ The viewer who successfully endures the picture's tensions is also rewarded for his pains.

\section{IV}

It should be clear by now that within only a few decades French art brought forth at least two fundamentally different models of historical painting. ${ }^{29}$ By way of comparison, the forms in literary history that correspond to these two models are the roman à thèse and the serial story: "In the roman à thèse ... the purpose is didactic or propagandist, and so the connectability of the textual schemata is carefully regulated. The number of blanks is reduced, and so too is the activity of ideation granted to the reader. ${ }^{30}$ The reader is permitted only the latitude necessary to give him the illusion that his own understanding has led him to adopt toward the state of affairs regulated by the text the attitude that in fact was expected of him. In contrast, the serial story, or speaking more generally the suspenseful, realistic narrative of the nineteenth century, relies on accumulation and variation of blanks, on cutting techniques, parallel plots, artificially limited perspectives, and so on. The reader of such fiction "is faced with a whole network of possibilities, and thus himself begins to formulate missing links. The temporary withholding of information acts as a stimulus, and this is further intensified by details suggestive of possible solutions. The blanks make the reader himself bring the story to life." ${ }^{11}$ The extensive and effective utilization of blanks by nineteenth-century realism can reach a point where these acquire an autonomy and can thus lead over into modernist art, which interrupts or misdirects communication both within and with the work, which "not only prevents connectability within the text but also makes it impossible for the text to be connected up to the reader's store of experience." ${ }^{32}$ The governing principle is then the law of rupture, which succeeds the laws of intelligibility and suspense. Gérôme does not, as we have said, go to this extreme, but it is unquestionable that he is feeling his way up to the very borders of this possibility.

The system of historical painting practiced by Gérôme is founded on the making of much greater demands on the beholder's activities than are made in Proudhon's art. Let us conclude, then, by speaking of the beholder, who has to 
accomplish all of this: bringing together what is unconnected; enduring the tensions; determining what is indeterminate. We have seen that the space of the beholder forms a continuum with the space of the picture, and that this space is also included as part of the picture's level of action in the form of a large blank, of a space in front of the picture and of a phase of time prior to the depicted scene. The beholder is, however, inscribed in this space as a relatively fixed element: his position can be reconstructed. Formally and geometrically, the result is nothing spectacular. There is no eccentric standpoint for the viewer, no extreme perspective such as the painting of this period likes to use to impress its public. At the middle of the picture's height and one third of its length from the picture's right edge, we can locate the point at which the viewer's regard enters the picture. The position of this point is a normal one and, given the structure of Gérôme's picture, is well chosen, as the eye, beginning at this point, must first move a small distance to the right, to the painting's lightest patch, to the blank, thus making first a counter movement before it follows the strong pull to the left, into the composition's perspectival depth.

The significance of the beholder's standpoint is not a result of geometry but rather of his position relative to the occurrence (nota bene, relative to, not within the occurrence). The beholder does not stand in a prolongation of one of the two axes of the action, nor is he aligned with the direction defined by the soldiers or the direction determined by their victim. In the space in front of the picture the soldiers formed an axis with Ney made up of two antagonistic vectors; in the picture they stand in a right-angled relation to each other. Thus they still remain antagonistic partners, and in each case the viewer remains "outside and in front of" their relation, unaffected by what transpired between them. His oblique position relative to the scene makes him the eyewitness of an event whose reality is presupposed. This expresses clearly the great difference between Gérôme's and Proudhon's pictures that was briefly mentioned earlier.

In the case of Proudhon's picture, the beholder's point of view, in terms of the depicted occurrence, in no way corresponds to the logic of the event. No one was able to stand there in the presence of the crime. In accordance with the general artistic practice of the period, an ideal viewer, a presuppositionless receptivity is assumed, and this is anticipated by the artist himself in the picture. The unrestricted, so to speak absolute visibility of the event is reception aesthetics' way of rendering the "thesis" of this picture, namely that nothing escapes the alertness of the gods and the state, and that every crime is punished. Recent studies in cultural history have pointed out the programmatically public nature and theatrical staging of judicial punishments during the Revolutionary era: "Punishments ought to be considered (1) not with regard to the guilty, but (2) with regard to the interests of society; now, the interests of society lie in setting a great example. The spectator must return home filled with terror. I do not believe that beheading as a form of execution is physically harsher than the 
gallows; but it has the advantage, for society, of being more frightening."33 According to an informed commentator on the preceding reflections, "One could hardly express more clearly and forcefully that revolutionary justice was inscribed in a system of communication, rather than a system of values, and that the spectacle death offered the spectator was a message the exchange of which constituted the law."34

This certainty is the stuff of which Proudhon made his picture. The painting is internally constructed with great assurance, and it is equally confident of its effect on the beholder. With Gérôme's picture, the viewer is placed in position to grasp the "pre-pictorial" event, which is no longer intended as a monitory example. His position is that of the eyewitness, not that of the one affected by the depicted action or that of the actor. The identification of the viewer with a figure in the picture, or a judgment on the action, is not "asked" of him or prescribed for him, as is done by Proudhon's picture. In this regard, therefore, the critic of the Salon was correct when he spoke of Gérôme's "undecided partisanship." The beholder stands on the "dead ground" between the parties to the event; it is just this fact that gives him the freedom to enter into the complicated game of "showing but not telling" that awaits him in the picture. The picture was painted in an era that no longer practiced publicly the "spectacle of death," one that had lost the firm belief in the effect on the public of the "mis à mort," and with it belief in the spectator's unequivocal reaction. It is no accident that this picture shows an execution that was carried out publicly, in keeping with the law, but that was decreed by those who feared the public's reaction and was for that reason performed at an unannounced time and in an unaccustomed place. Proudhon's viewer is an interested party and also sits in judgment; he represents the function of the public by the very fact of being present (without being present as an individual). In contrast, Gérôme's beholder impresses us as someone who is as isolated and thrown entirely upon his own resources as what confronts him in the picture. He is someone who comes upon the scene almost by accident and must first make sense of what he sees.

The realism that we treated first and the neutrality of the beholder's standpoint that we discussed last both indicate that this form of historical painting no longer conveys explicitly political messages. The condemnation of Ney and his execution on 7 December 1815 had been a political affair of the first order of importance in Europe. The marshal had incurred a grievous guilt when he betrayed the cause of the Bourbons in 1815 and went over to Napoleon, taking his troops with him. The legal proceedings initiated against him, however, were not only extremely questionable from a juridical point of view -in addition, their conclusion was dictated by the political motive of finding a scapegoat for the "Hundred Days." Ney's rehabilitation was not accomplished quickly, but by the 1860s it had been achieved: his bust was placed in the Pantheon; the judgment on him was annulled; and in 1853 François Rude's monument to him was dedi- 


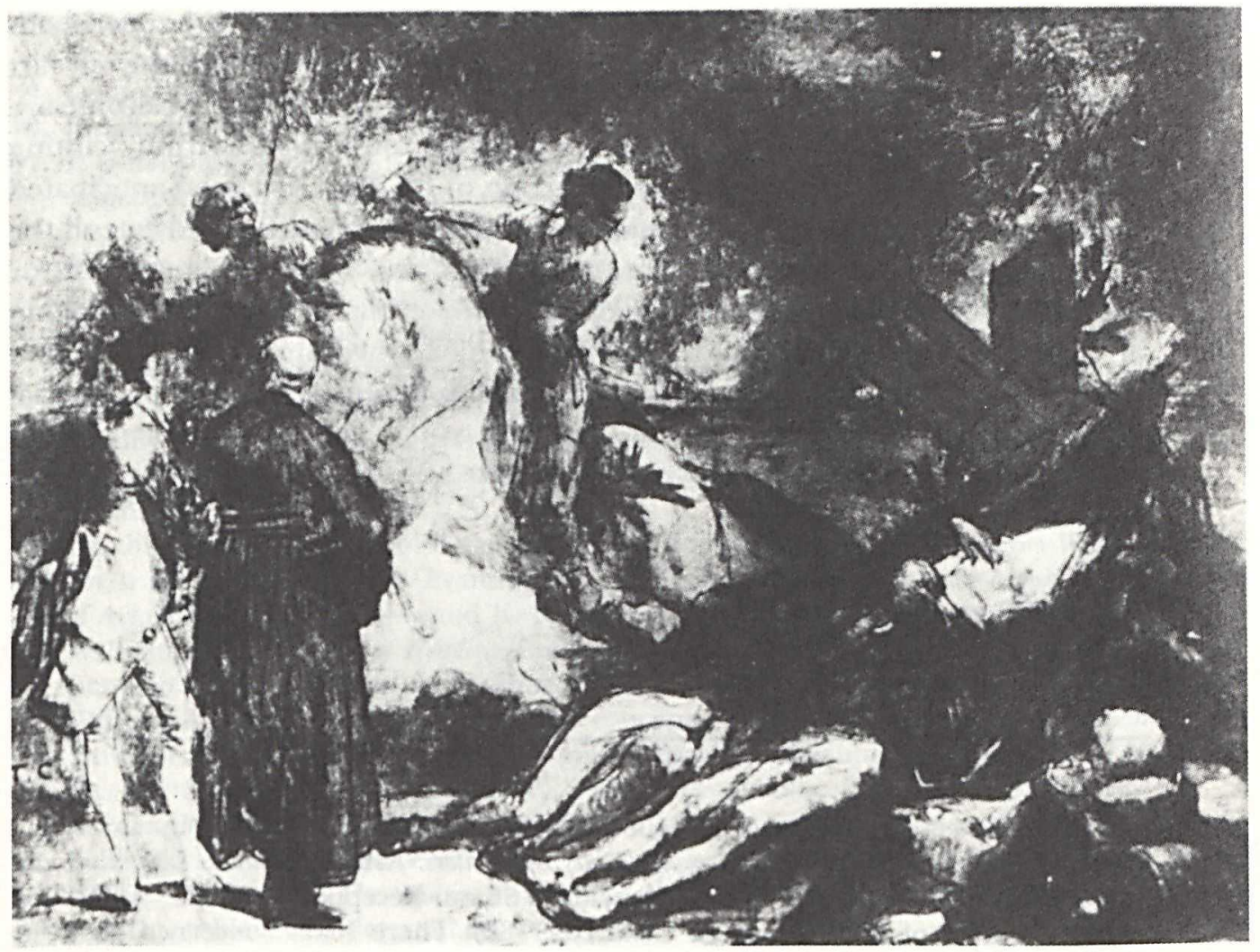

FIGURE 4. Thomas Couture, sketch for a destroyed painting, 1815. Present location unknown. Reproduced after Albert Boime, Thomas Couture and the Eclectic Vision (New Haven, 1980; see note 35).

cated on the site of his execution, which had been a modest place of pilgrimage since Ney's death. ${ }^{35}$ Hence Gérôme did not intervene in an undecided rehabilitation suit with his choice of a subject, nor did he ingratiate himself with the government of Napoleon III. The topic had reverted to the public domain, and anyone who looked for a pro or a contra in Gérôme's treatment of it could discover evidence for both positions. The artist responded to the predictable criticism of the Ney family with the argument that "painters have the same right to write history with their brushes as writers with their pens. Furthermore, the picture was only the statement of a well-known fact, without any commentary."36

History supplies material for this kind of historical painting, not thesesmaterial for the generating of tension and for self-presentation. Indubitably, a conflict appears in this type of historical painting that quickly grows in size, and that also runs through Gérôme's picture. The extraordinarily skillful use of space 
for narrative purposes and the no less masterful way the wall is painted both ultimately call for independent treatment in their own right, which they in fact received in the subsequent decades. The successors of the narrator Gérôme are the cameramen and the film directors. Eisenstein found that Griffith's cutting technique and the way he managed the action of his films had been anticipated by the narrative methods of the realist Dickens. ${ }^{37}$ It is not difficult to extend the parallels further, to nineteenth-century painting. Art was the great school for the cultivation of an attitude on the part of the viewer that is active, without being an existential engagement, for the continuation of a medium that seems to have more blanks than places of determinacy, and yet consists entirely of "special arrangements."

- Translated by Raymond Meyer

\section{Notes}

This article is an attempt to continue from the other end, so to speak, the investigations contained in my book Der Anteil des Betrachters: Rezeptionsästhetische Studien zur Malerei des 19. Jahrhunderts (The Beholder's Share: Reception-Aesthetic Studies on the Painting of the Nineteenth Century; 1983). There I was concerned with the "determinacies" in the picture, with the "aids to reception"; here it is a matter principally of the "places of indeterminacy," which are no less suited than the aids to reception to guide the viewer's perception. The title comes from a remark by Jean Cocteau, one that was in fact made about the cinema. Cocteau's statement can be found in Stephen Heath, Questions of Cinema (London, 1981), 114.

1. Georg Wilhelm Friedrich Hegel, Aesthetics: Lectures on Fine Art, trans. T. M. Knox (Oxford, 1975), 2: 858-59.

2. Johann Wolfgang von Goethe and Johann Heinrich Meyer, "Über die Gegenstände der bildenden Kunst," in Propyläen 1, no. 1 (1798; reprint ed., Stuttgart, 1965): 72.

3. Hegel, Aesthetics, 1: 265.

4. Ernst Förster, "Aus dem gegenwärtigen Kunstleben am Rhein und in den Niederlanden," in Kunstblatt (1843), $110 \mathrm{ff}$., quoted from Kunsttheorie und Kunst des 19. Jahrhunderts in Deutschland, ed. Werner Busch and Wolfgang Beyrodt (Stuttgart, 1983), 188. On the idealist distinction between truth and verisimilitude, idea and fact of history, see the chapter devoted to these topics in Karl Schawelka, Eugène Delacroix: Sieben Studien zu seiner Kunsttheorie (Munich, 1979), 94ff.

5. The most recent work on this subject is Jörg Traeger, "Als ob einem die Augenlider weggeschnitten wären," in Kleist-Jahrbuch (1980), 86ff.; an earlier treatment is Robert Rosenblum, Transformations in Late Eighteenth-Century Art (Princeton, 1969).

6. With regard to this work, see the monographic discussion of it by Helen Weston, "Proudhon: Justice and Vengeance," in The Burlington Magazine 117 (1975): 353ff. See also the catalogue of the exhibition The Age of Neoclassicism (London, 1972), 139. 
7. As regards this version, see Weston, "Proudhon," 354, figs. 24-27.

8. Quoted from Gazette des beaux-arts 6 (1860): $310 \mathrm{ff}$.

9. Quoted from Walter Friedlander, David to Delacroix (Cambridge, Mass., 1952), 57.

10. Rosalind Krauss, Passages in Modern Sculpture (Cambridge, Mass., 1981), 10.

11. It is not possible, nor is it necessary here, to compile a list of the literature on the subject of realism. I shall name only two recent articles representing opposed positions, which provide extensive bibliographies: Jörg Traeger, "Die Sprengung des Idylls: Ein Beitrag zur Realismusdebatte," in Katalog der Ausstellung Wilhelm Busch (Hanover, 1982), 1: 3ff., and Friedrich Gross, "Realisten des 19. Jahrhunderts als Idylliker," in Kritische Berichte 11, no. 2 (1983): 58ff. The best introduction is still Linda Nochlin, Realism (Harmondsworth, 1971). This work also contains discussions at some length of the iconography of death in the nineteenth century.

12. On this question, see the numerous writings of Werner Hofmann, which can be found in his Das irdische Paradies (Munich, 1960), Nana (Cologne, 1972), and Bruchlinien (Munich, 1979).

13. On the concept of "place of determinacy," see Roman Ingarden, The Literary Work of Art, trans. G. G. Grabowicz (Evanston, Ill., 1973), and The Cognition of the Literary Work of Art, trans. R. A. Crowley and K. R. Olson (Evanston, Ill., 1973). On "blank," see Wolfgang Iser, The Act of Reading (Baltimore, Md., 1978), 170ff., and "Interaction Between Text and Reader," in The Reader in the Text, ed. S. R. Suleiman and I. Crosman (Princeton, N.J., 1980), 106ff. On Iser's concept, see W. Reese, Literarische Rezeption (Stuttgart, 1980), 36ff. (this work also gives a practical initiation into the methods of reception aesthetics); P. U. Hohendahl, "Introduction to Reception Aesthetics," in New German Critique 10 (1977): 29ff.; H. J. Schmidt, "Text-Adequate Concretizations and Real Readers: Reception Theory and Its Applications," in New German Critique 17 (1979): 157ff.; G. H. Hartmann, Criticism in the Wilderness (New Haven, 1980), $265 \mathrm{ff}$. (on the problem of indeterminacy in general).

On "suture," the most recent works are Stephen Heath, Questions of Cinema (London, 1981), 76ff., and Noel Carroll, "Address to the Heathen," in October 23 (1981): $89-163$, which also lists the older literature. The concept of "suture" seems to have arisen independent of literary aesthetics. Although it uses "suture" to refer, on the functional and structural levels, to the same phenomenon designated by "place of indeterminacy" and "blank," film theory has something much larger in mind than literary theory. It regards the "suture" not just as the "matrix of text-reader interaction" but also as the locus of the production of ideology, a matter that cannot be treated here.

I know of no previous application of these concepts to the objects studied by art history. The investigation most closely approximating the analyses of literary theory and our own reflections presented here is Donat de Chapeaurouge, "Die Phantasie des Betrachters," in Der frühe Realismus, 1800-1850 (exhibition catalogue; Nürnberg, 1970), 3-11.

In a certain respect, however, the invention of the concept of the "blank" can be claimed by art history. I am alluding to a statement made by Paolo Veronese in his famous interrogation by the Inquisition in Venice in 1573: "But when a space is empty in a painting [se nel quadro si avanza spacio], then I enrich the picture with additional figures drawn from the Holy Scriptures." The difference between "spacio avanzato" and "blank" is that what is deliberately filled in the case of the former is intentionally left empty in the latter case. I was reminded of Veronese's relevance to the concerns of the present article by Max Kozloff's lovely essay, "The Awning That Flapped in 
the Breeze . . ," in Artforum, September 1981, 53-60, which also served as a helpful stimulus to my thoughts on other aspects of this study.

The great precursor of the theoreticians of the blank is Eisenstein. See his concept of the "zero-point" and his analysis of W. I. Surikow's painting The Boyaress Morosova, in which he maintains that the golden section indicates an "empty place," which nevertheless emphasizes what is most important in the picture but cannot be presented graphically, namely the words of the boyaress. See Serge Eisenstein, "Über den Bau der Dinge," in Gesammelte Aufsätze (Zurich, n.d.), $224 \mathrm{ff}$.

14. Gotthold Ephraim Lessing, Laokoon, in Sämtliche Schriften, ed. Karl Lachmann and Franz Muncker (Stuttgart, 1893), 14: 355.

15. G. E. Lessing, Laocoön, trans. E. Frothingham (Boston, 1890), 16ff. On Lessing's anticipation of the concept of the blank, see Das Laokoon-Projekt: Pläne einer semiotischen Ästhetik, ed. G. Gebauer (Stuttgart, 1984), $66 \mathrm{ff}$.

16. Denis Diderot, Salons: Texte établi et présenté par Jean Seznec et Jean Adhémar (Oxford, 1975), 1: 205.

17. Iser, Act of Reading, 182.

18. Ibid., 183.

19. On this work, see C. Moreau-Vauthier, Gérôme: Peintre et sculpteur (Paris, 1906), 253ff.; G. M. Ackermann, "Gérôme and Manet," in Gazette des beaux-arts 70 (1967): 169ff.; G. M. Ackermann, catalogue of the exhibition Jean-Léon Gérôme, 1824-1904 (1972-73), 64ff. The picture belongs to the Sheffield City Art Galleries, Sheffield, England. The size of the picture is $64 \times 103 \mathrm{~cm}$. A short, very accurate characterization of Gérôme's art is given by Albert Boime, "Jean-Léon Gérôme, Henri Rousseau's Sleeping Gypsy and the Academic Legacy," in The Art Quarterly 34 (1971): 3ff.

20. Jules Grangedor, "Le Salon de 1868," in Gazette des beaux-arts 25 (1868): 18.

21. B. M., "Die akademische Kunstausstellung," in Zeitschrift für Bildende Kunst 4 (1869): 15.

22. See Michael Fried, Absorption and Theatricality: Painting and Beholder in the Age of Diderot (Berkeley, 1981).

23. On the concept of narrative space, see Stephen Heath, Questions of Cinema, 19ff.

24. Lessing, Laocoön, 126. [I have amended the translation of this passage; Frothingham's version reads: "whose parts lie near together"-Trans.]

25. Ludwig Igelsheimer, "Die belgischen Bilder," in Jahrbücher der Gegenwart 2 (1844): 24ff., quoted from Kunsttheorie und Kunstgeschichte, 200, n. 3.

26. See Roland Barthes, "Structural Analysis of Narratives," in Image, Music, Text, trans. Stephen Heath (New York, 1977), 122: "What has been disjoined at a certain level (a sequence for example) is most often joined again at a higher level (a hierarchically important sequence, the global signified of a number of scattered indices, the action of a class of characters)."

27. Jules Lucas-Dubreton, Le Maréchal Ney, 1769-1815 (Paris, 1941), 327.

28. Here a remark of Albert Boime is pertinent: "Like Gérôme, Couture permitted himself a dip into actuality and modernistic expression only when they could be legitimized by allegorical overtones"; Thomas Couture and the Eclectic Vision (New Haven, 1980), 48.

29. It is hardly possible any more to obtain an overview of the literature on nineteenthcentury historical painting. See the most recent summary in H. T. Wappenschmidt, Allegorie, Symbol und Historienbild im späten 19. Jahrhundert (Munich, 1984). On French historical painting, see the scattered beginnings of a compilation of the literature in Friedlander (see note 9 above); J. C. Sloane, French Painting Between the Past and the 
Present (Princeton, N.J., 1951), and the monographic studies of Couture (A. Boime), Delaroche (N. D. Ziff), Géricault (L. Eitner), and Manet (N. G. Sandblad, A. C. Hanson, G. Mauner). The selection of my examples should not be understood as implying that Proudhon and Gérôme were path-breaking innovators. The generation preceding Proudhon was already elaborating the solution he employed, and Gérôme's blanks probably have their origin with his teacher Delaroche. The works I chose for examination represent ideal types.

30. Iser, Act of Reading, 189.

31. Ibid., 192. [I have amended the translation of this passage slightly-Trans.]

32. Ibid., 194.

33. Le Moniteur, no. 155, session of 4 June 1791. Quoted from Marie-Hélène Huet, Rehearsing the Revolution: The Staging of Marat's Death, 1793-1797 (Berkeley, 1982), 29ff.

34. Ibid., 30. Cf. Michael Foucault, Discipline and Punish: The Birth of the Prison, trans. Alan Sheridan (New York, 1977), chaps. 1 and 2.

35. An important source of information about Ney's death and posthumous fame are the memoirs of the eyewitness Léon Rochechouart, Souvenirs sur la Revolution, l'Empire et la Restauration (Paris, 1889). Of the more recent biographies I recommend Jules LucasDubreton (see note 27 above), and H. Kurtz, The Trial of Marshal Ney: His Last Years and Death (New York, 1957). On the consequences for art history, especially on Rude's statue of Marshal Ney, see Ruth Butler, "Long Live the Revolution, the Republic, and Especially the Emperor!: The Political Sculpture of Rude," in Art and Architecture in the Service of Politics, ed. Henry A. Millon and Linda Nochlin (Cambridge, Mass., 1978), $92 \mathrm{ff}$.

In the oeuvre of Couture there is a remarkable parallel to Gérome's picture, his allegorical composition 1815, which was destroyed in the Franco-Prussian War of 1870-71, but of which a preparatory sketch has been preserved (fig. 4). At the French border, marked by a broken post bearing the inscription "1815 France," the embodiments of the ancien régime, a returning émigré and a priest, come upon fallen soldiers of Napoleon's army wrapped in the tricolor, while in the background the fires of the battlefield of Waterloo are blazing. As Boime argues, this declaration of allegiance to Napoleon and to his successor Napoleon III must date from the beginning of the 1860 s (see note 28 above). In accordance with the criteria formulated above, we would compare the picture's manner of demonstration with the roman à thèse and call it tableau à thèse.

36. Quoted from the catalogue of the exhibition Jean-Léon Gérôme, 1824-1904, 65 (see note 19 above). See also the continuation of the quotation in Moreau-Vauthier's book, which uses a different source than Ackermann: "Les légitimistes disaient: Quel flagorneur du gouvernement! Les bonapartistes: Que lui a-t-on fait? Il n'est donc pas encore content et pourtant on l'a nommé naguère officier de la Légion d'Honneur! etc. ... Que pensez-vous de ces façons de parler contradictoires?” [The legitimists said: How he licks the government's boots! The Bonapartists said: What has been done to him? He's still not satisfied, even though he was made an officer of the Legion of Honor not long ago! etc. ... What do you think about these contradictory ways of talking?], p. 254ff.

37. Sergei Eisenstein, "Dickens, Griffith, and the Film Today," in Film Form, trans. Jay Leyda (New York, 1957), 195ff. 